\title{
80’lerden Yükselen Bir Ses: küçük İskender ve "bir nedeni yok yalnıca öptüm” Adlı Şiirini Okuma Denemesi
}

\author{
Dr. Öğr. Gör. Hafize Şahin ${ }^{1^{*}}$
}

"Oysa ben insanları her șeye rağmen artniyetsiz sevebilecek kadar faşistim. "the good son" adlı denemeden alıntılanmıştır. Underground Otopark, (2009a, s.198).

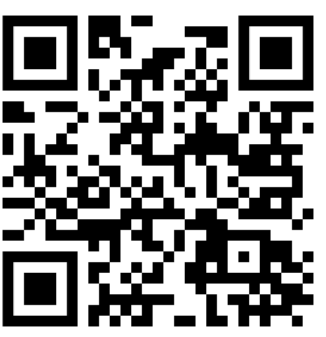

Geliș tarihi: 23.09.2020

Kabul tarihi: 29.10.2020

\section{Atıf bilgisi:}

IBAD Sosyal Bilimler Dergisi

Sayı: Özel Sayı Sayfa: 244-255

Yll: 2020

This article was checked by iThenticate. Similarity Index 10\%

Bu makalede araştırma ve yayın etiğine uyulmuştur.

1 Hacettepe Üniversitesi TÖMER, Türkiye, hafize@hacettepe.edu.tr, ORCID ID 0000-0002-9705-9302

\footnotetext{
* Sorumlu yazar
}

\section{öz}

küçük İskender, 1964-2019 yılları arasında İstanbul'da yaşamış önemli bir modern Türk şairidir. Hayatı boyunca marjinal olarak görülen şair, daha sonra kendisi marjinal sıfatını benimsemiş ve kendine özgü bir duruş sergilemiştir. Yaşamda kendisi gibi olmayı seçen sanatçı; normatif hayatın dayatmalarını, otoriteyi ve toplumsal kuralları eleştirmekten çekinmemiştir. İyiliğin ancak dürüst, samimi ve gerçekçi bir perspektiften ortaya çıkabileceğine inanmıştır. Kitaplarında Beyoğlu, queer, İstanbul, rakı, eşcinsellik, Orta Doğu, sinema ve müzik gibi çeşitli konuları ele almıștır. Bu çalışmada öncelikle küçük İskender'in üslubu hakkında bilgi verilecek, sonra göstergebilim ve dilbilim alanlarından faydalanılarak "bir nedeni yok yalnızca öptüm" adlı şiiri incelenecektir. Yazının amacı; modern Türk şiirinin özgün bir ismi olan küçük İskender'in 1980'lerde filizlenip zamanla boy verip gelişen 2000'lere uzanan şiir macerasını takip etmek, isyankâr tutumunu anlamak ve şaire hakkını teslim etmek isteğidir.

Anahtar Kelimeler: küçük İskender, öpmek eylemi, göstergebilim, modern Türk şiiri. 


\section{A Voice Rising From The 80s: küçük İskender And An Attempt to Reading His Poem Which Named "I have no purpose I just gave a kiss"}

\section{Dr. Lec. Hafize Şahin ${ }^{1 *}$}

First received: 23.09 .2020

Accepted: 29.10.2020

\section{Citation:}

IBAD Journal of Social Sciences

Issue: Special Issue

Pages: 244-255

Year: 2020

This article was checked by iThenticate. Similarity Index 10\%

${ }^{1}$ Hacettepe Üniversitesi TÖMER, Turkey, hafize@hacettepe.edu.tr,

ORCID ID 0000-0002-9705-9302

\section{* Corresponding Author}

\begin{abstract}
küçük İskender is an important modern Turkish poet who lived in Istanbul between 1964-2019. The poet, who was seen as marginal throughout his life, later adopted the title of himself marginal and took a unique stance. The artist who chooses to be like himself in life; he did not hesitate to criticize the impositions of normative life, authority and social rules. He believed that good can only emerge from an honest, sincere and realistic perspective. In his books, he covered various topics such as Beyoğlu, queer, Istanbul, raki, homosexuality, the Middle East, cinema and music. In this study, first of all, information about the style of küçük İskender will be given, then his poem "I have no purpose I just gave a kiss" will be examined by using the fields of semiotics and linguistics. The aim of the article; It is the desire of küçük İskender, who is an original name of modern Turkish poetry, to follow the poetry adventure that sprouted in the 1980s grew in time and came to time 2000s, to understand his rebellious attitude and to give the poet his right.
\end{abstract}

Keywords: küçük İskender, the act of kissing, semiotics, modern Turkish poetry. 


\section{GİIŞ}

28 Mayıs 1964 doğumlu şair, yazar, oyuncu küçük İskender; 3 Temmuz 2019 tarihinde hayata veda etti. Ardında pek çok şiir, deneme, anı, şiir-masal, şiir-öykü gibi türlerin iç içe geçtiği metinlerden oluşan büyük bir külliyat bıraktı. Bu külliyattaki metinlere bakıldığında küçük İskender'in üslubunu belirleyen unsurun "edebî türler arası salınım" olduğu söylenebilir. Ortadoğu, eşcinsellik, queer, kentli faşizm, Beyoğlu, cinsiyet algısı, şairlik, çocukluk, Beat yazarları, rakı, beden algısı, müzik, sinema gibi farklı konularda yazdı. Türk edebiyatını takip ettiği gibi dünya edebiyatındaki yazar, şairleri de okuyan; metinlerinde anan küçük İskender için nevi şahsına münhasır bir şair yakıştırması yerinde olur. küçük İskender, toplumsal hayatın akışını belirleyen basit algıları metinlerinde yeniden inşa ederken kendi varlığını anlamaya çalışır, dayatmaların dışında kalır. Evlilik, çocuk, iş üçgenindeki normatif yaşamdan uzak durur. Cerrahpaşa Tıp Fakültesini son sınıfta terk eder. Terk edişin sebebi, bir meslek insanı olmanın getirdiği döngüsel yaşamın dışına çıkmak isteğidir. Standart söylemin dışındaki üslubu ve şiir anlayışı ile hafizalarda yer eden bir şair olarak neden çok ses getirdi küçük İskender'in yazdıkları? Her şeyden önce çok okuyan, geniş bir birikimle yazan bir şair olduğunu belirtmek gerek. Ancak çok okumak tek başına, çok okunabilen bir şair ya da yazar olabilmeyi sağlamaz. küçük İskender'in şiiri, samimiyet, gerçekçilik ve dikbaşı bir söylemden vazgeçmemesi ile karakter kazanır. Saldırgan bir tavır sergiliyor gibi görünse de; kaba söz, argo, şiddet içeren bir dil kullansa da hayata dair ümidi olan bir insan ruhu her daim yazılarında gözlemlenebilir. "Ben doktor değil, çöpçü olmak istiyorum. (...) Komünal dünyaya katılmam anca böyle mümkündü - gittim, şairliğe yazıldım" (2018, s.17) cümlelerinden onun şairliği bir varoluş şekli olarak seçtiğini anlarız.

Şairliği yaşam biçimi hâline getiren küçük İskender'in 80 'lerde başlayan şiir macerası, günümüze 2000'lere kadar gelir. Bu çalışmada öncelikle şairin şiir anlayışı üzerinde durulacak, ardından şairin üslubunu belirleyen yazma tekniklerinden bahsedilecek ve son olarak "bir nedeni yok yalnızca öptüm" adlı şiir, "öpmek” eyleminden hareketle analiz edilecektir.

\section{KÜÇÜK ${ }^{1}$ ISKKENDER'İN YAZIN ANLAYIŞI ÜZERINE BİRKAÇ SÖZ}

küçük İskender'in ilk şiir kitabı Gözlerim Sığmıyor Yüzüme 1988'de yayımlanır. 1999'da yayımlanan Bir Çift Siyah Eldiven şiir kitabıyla Orhan Murat Arıburnu ödülünü, 2006'da İskender'i Ben Öldürmedim kitabıyla Melih Cevdet Anday şiir ödülünü, Elli Belirsiz kitabı ile 2014'te Erdal Öz edebiyat ödülünü, 2017’de Mayıs Giremez kitabı ile Behçet Necatigil şiir ödülünü alır. 2018'de ise Yunus Nadi şiir ödülü, küçük İskender' in Ölen Sevgilimin Şiir Defteri ile Yücel Kayıran'ın Efsus'a Yolculuk kitaplarına verilir.

küçük İskender, edebî bir türün sınırlarını gözeterek yazmaz; kitaplarına tek tek bakıldığında denemede şiir parçalarına, şiirde deneme türünden kopmuş paragraflara rastlamak mümkündür. Şairin üslubunu belirleyen bir öge olarak türlerde nasıl kalem oynattı̆̆ından bahsetmek yerinde olacaktır. Şairin bir metnini bir türe dâhil etmeye çalışmak yerine, "edebî türler arası salınımı" kabul ederek okumak şairin daha iyi anlaşılmasını sağlayacaktır. Şairin 1988-2019 yılları arasında yazdığı metinleri, şiirleri, denemeleri yaşamı boyunca okurla buluşur. küçük İskender'in toplam 71 eseri yayımlanmıştır. Bu kitapların kimi daha önce yayımlanan kitapların bir arada yayımlanması ile oluşturulmuştur.

küçük İskender, marjinal şair olarak edebiyat çevrelerinde anılır. Marjinal sıfatı, heteroseksist toplumsal yaşamdan uzak oluşu ile ilişkilendirilebilir. Nilgün Marmara, Lâle Müldür, Edip Cansever gibi edebiyatta yankı bulmuş şairlere metinlerinde selam verir; genç şairlerin şiirlerini de yakından takip eder. Özellikle Eflatun Sufleler kitabı son dönem Türkiye'sindeki genç şairler üzerine değerli bilgiler içerir. Hırçın, agresif, ele avuca sığmaz küçük İskender; çocuk masumiyetini korumak arzusu ile adının "küçük" sıfatı ile anılmasında karar kılar. Poetikasını ele aldığı ve genç şairlere önerilerde bulunduğu Rimbaud'ya Akal Notları adlı kitabında "küçük" sıfatında nasıl karar kıldığını şöyle anlatır:

Doktor olacaktı. Herkes öyle istiyordu. Herkes ondan paramparça bir ülkede çıarları ego tatminleri doğrultusunda bir şeyler istiyordu. küçük İskender imzası tesadüfen

\footnotetext{
${ }^{1}$ Şairin adı "küçük İskender” şeklinde küçük harflerle yazılmalıdır, şairin tercihi bu yöndedir; ancak makalede derginin yazım kuralları gereğince ana başlıklar büyük harfle yazılmıştır. Şairin adı küçük harflerle "küçük İskender", büyük harflerle "KÜÇÜK İSKENDER” şeklinde yazılmalıdır. Şairin yayımlanan eserlerinde de küçük, büyük harf kullanımında bu yazımları görmek mümkündür. Makalemizde şairin adı metin içinde geçtiğinde küçük harflerle ve başlıklarda ise büyük harflerle yazılmıştır.
} 
gelmişti; büyük adam olacaksın lafinı sarfeden arkadaşları bir gün, büyük sıfatını İskender'le birleştirince, o da bu saptamayı ironik olarak, ne büyük İskender'i, ben olsa olsa küçük İskender olurum'a dönüştürmüştü; gülüşülünmüştü uzunca. Yı1, yine 1980'di.

Ne zaman ki, bir tarih kitabında annesiyle birlikte, amcası tarafından öldürülen küçük İskender'i ve babası Büyük İskender'i okudu o delikanl1, karar verdi devrimin saflarında altı yaşlarında katledilen bir sübyanın namını taşımaya (2009b, s. 61-62). ${ }^{2}$

Altı yaşındaki küçük bir çocuğun imgesini sahiplenmek aynı zamanda saflığı, temizliği ve kendini bilmeyi; şairin ne kadar önemsediğinin göstergesidir. O, şiir yaşamında yazdıkça "küçük", "çocuk" kalabilmeyi, çocuk saflığı ile hayatı algılayıp şiire yansıtabilmeyi amaçlamıştır.

küçük İskender'in yaşamında 1980 yılı bir kırılmayı ifade eder. 1980 döneminde yaşananlar onun aile hayatında, çocukluğunda da izler bırakmıştır. Rimbaud'ya Akıl Notları kitabının kapağını çizecek kadar resim kabiliyeti olan küçük İskender; eşcinselliği bir eğilim değil yönelim diye gösterir. 1990’larda ise sinemada A ̈̆ır Roman filminde rol alır.

Zaman zaman medyada fazla yer alması nedeniyle eleştirilse de o medyayı görünür kılmak için kullandığını şöyle anlatır:

Medya beni değil, ben medyayı kullanıyorum. Bir aile dergisinde eşcinselliği, şizofreniyi savunarak "kör olasın demiyorum, kör olma da gör beni" taktiğini uyguluyorum. (...) Pop olmaktan asla çekinmedim. Yolumu biliyorum. Bilinçli davranıyorum. Dar edebiyat çevrelerinin yobaz tutumları arasında sıkışıp kalmak beni kahrediyor. Türkiye'de yeni bir şair kimliği gelişiyor; ben de bu insanlar arasındayım. Açık, rahat, pervasız, inançlı, tutkulu, zaafları olan, cesur şairler. Pısırıklığa lanet yağdıran şairler (Metin, 1993, s.63).

$\mathrm{Bu}$ bağlamda şairin medyayı görünür olmak için kullanması, onun şiirinin popülerleşmesinin sebeplerinden biridir.

küçük İskender'in üslubunu sözcük seçimi, şairin cesareti, çalışkanlığı şekillendirir. Şair modern Türk şiirinde yeni bir söylem üretmeyi başarmıştır. Şair de bunun farkındadır. Erotika kitabından yola çıkarak Celâl Metin, pornografik bir eser yazmanın ne dereceye kadar mümkün olduğunu sorduğunda küçük İskender Erotika' da kullandığı dilin pornografik olduğunu söyler. Argonun şiir diline girdiğinde şiirin büyüsünün bozulduğunu düşünenlere katılmaz. Argonun yaratıcılıkla ilişkisine dikkat çekerek kasabalılığı reddetmek gerektiğine inanır ve "Halk Edebiyatı'nın karşısında çağdaş bir divan şairi olarak durduğumun da farkındayım" (Metin, 1993, s.61) der.

Medyayı kullanmasının yanı sıra hayattaki tavrı da onun şiirinin popüler kültürde yer almasını sağlamıştır. Ali Özgür Özkarcı, “anti-kurumsallaşmanın özellikle 90'lardan sonraki yaygınlığı”nın (2014, s.115) onun şiirinin popülerleşmesine imkân sağladığını belirtir.

\section{KÜÇÜK İSKENDER'IIN ÜSLUBU}

Beden, bedene ait unsurlar, toplumda yaşanan cinayetler, üçüncü sayfa haberleri küçük İskender'in eserlerinde kendine yer bulur. Şair, her kitabında bir öncekine eklemlenen ama ondan başka bir yere doğru da açımlanan bir fikrin, duygunun peşindedir. Alışılmamış kelimeleri bir arada kullanmak, gelenekten hareket ederek post-modern anlayışla sözcükleri yıkıp kurmak, "naiflik" değil de agresiflik onun şiirinde öne çıkar. Şiir anlayışındaki sert, yalın gerçekliği ifade ettiği bir dil ve üslubu bilinçli olarak kurduğunu şöyle dile getirir:

Şair, işbirlikçi değil, işbitiricidir. Tabancasındaki tek kurşunla karşısındaki ordunun tamamını vurduğunu hayal eder, hatta buna inanır.

$(\ldots)$

\footnotetext{
${ }^{2}$ Şair, Lucifer’in Bisikleti adlı kitabının son yazısı "küçük İskender” başlığında, küçük İskender'in tarihteki yeri üzerinde durur (2007, s.181-182). Alıntılarda, şairin imlasına sadık kalınmıştır.
} 
Nesnenin, nesnelin arkasına geçmek, onun boyutunu deforme etmek, perspektiflerin açılarını sorgularken fen ile düş'ü birbiriyle örtüşen fonksiyon aşamasına getirebilmek naif sanatçının limitini aşar. Bir şairi bekleyen en büyük tehlikelerden biridir naiflik ve bu naiflikle övünme konumu (2009b, s.82).

“ 'Meçhule giden bir gemi' gibi değil, belli bir hedefe sıkılmış kurşun gibi ilerlemek” (2009b, s.46) anlayışı ile şiir yazar. küçük İskender' in metinlerinde, şiirlerinde, günlüklerinde, romanlarında pervasız, salvotik $^{3}$ bir üslup hâkimdir. Bunu yaparken kes-yapıştır (cut-up) tekniğinden, kendiliğinden (spontane) düzyazı tekniğinden ve parçalı (fragmental) anlatımdan yararlanır. Kesip bölerek, parçalayarak kendi bütününe ulaşır; şiirde kendi atmosferini yaratır.

küçük İskender, Cangüncem kitabında "Türkçe yazsam da Türkçe Şiir'in dışında”yım (küçük İskender 2012, s.8; Celâl, 1993, s.62) der. Böyle söylese de Türk şiiirinin son dönemde ses getiren önemli bir şairi olarak adından sıkça söz ettirir. Onun şiirini Türk kültürü, ülkede yaşananlar, kısacası yaşanılan coğrafya şekillendirir. Entelektüel birikimi ile okuruna da işaretler bırakır, okurun eline kalemi vererek doğru bildiği yanlışların üstünü çizmesini sağlar. Şiiri, karanlık bir odada 1şıkları yakarak nesnelerin kendi gerçekliğiyle algılanmasını sağlayacak bir anlayışla hayatın akışına bir müdahale olarak kurgular. Onun şiirinin özellikleri şöyle sıralanabilir:

1. Gelenekten beslenen ama geleceği kuran bir şiir anlayışı vardır.

2. Yıkıcı, bozucu, yapıcı ve insandan ümidini kesmeyen bir dil ile şiir yazar.

3. Alışılmamış kelimeleri bir arada kullanır, farklı kelime birliktelikleri ve zıtlıklar ahenkle yansıtılır.

4. Salvotik bir dil kullanır. Ardı ardına savrulan kelimeler okurun yüzüne gözüne bulaşır.

5. İyilikten değil kötülükten öğrenme deneyimlerini aktarır.

6. Hoşa giden konuları değil de hoşlanılmayan konuları ele alır.

7. Parçalı (fragmental) bir yazım tekniği kullanır.

8. Ortadoğu, eşcinsellik, queer, kentli faşizm, Beyoğlu, cinsiyet algısı, şairlik, çocukluk, Beat yazarları, rakı, beden algıs1, müzik, sinema gibi farklı konularda yazar.

9. Popüler algıyla değil sahici bir anlayışla yazar, hakikati arar.

10. Lirizmi çağrışımı bilinen iyilikle bağdaştırılan kelimelerle kurmaz; lirizmi agresif, kötü, günlük dilde ağza alınmak istenmeyen argo kabul edilen sözcüklerle kurar.

11. Metaforik bir üslup sahibidir.

12. Üretken ve çok yazan bir şairdir. Zaman zaman tekrarlar farklı metinlerde göze çarpar.

13. 1980'lerden 2000'lere istikrarlı bir yazın hayatı olmuştur.

küçük İskender, "bir politika içinden, bir disiplin içinden" değil de "hissiyatın içinden, kültürel yaşantıdan" gücünü alan ve "her açıdan karşı bir yerden, ama ideolojisi olmayan bir yerden" (Özkarcı, 2014, s.93) konuşmayı tercih eder. Bir grubun, bir kitlenin ya da bir görüşün şairi olmak gibi bir tavır sergilemez. küçük İskender'in üslubunda öne çıkan isyankâr bir tutum vardır; şair, gerek şiirlerinde gerekse düzyazı türündeki metinlerinde bu saldırgan tavırdan vazgeçmez. Ehlileşmiş bir dil yaratmak arzusunda değildir.Toplumla, normatif yaşam döngüsüyle bağdaşamaz, bilinçli bir yalnızlığın kapılarını aralar. Özgürlüğü, normatif yaşamın dışında kalmakla eşdeğer sayar. Cangüncem adlı günlüğünde, "salvotik tavır", "salvotik hareket" diye tanımladığı isyankâr tutumunu şöyle açıklar:

salvotik tavır, yalnızca kurulu düzen aksaklıklarına, sakatlıklarına mı yönelik? elbette, hayır! Daha geniş bir algılama sahası yaratmayı engelleyen ahlaki sınırlamaları ve bunların şiddetli savunucuları da bu salvo hareketinden paylarına düşen darbeyi yemelidirler (2012, s.69).

\footnotetext{
${ }^{3}$ küçük İskender'in Eflatun Sufleler kitabında şiir bağlamında bu kelime geçer (2013, s.21, s.27, s.57).
} 
küçük İskender, "salvo hareketi”ni ise dokuz maddede açıklar. Bu hareket bireyi önemser, bireyin yönlendiği ara zamanı dikkate alır, salt onu kuşatır ve bu şiir sadece bireyle soluk alır. Yazılan şiir ne kadar hüzünlü ise bir o kadar ironi yüklüdür. İmge içinde acı ve alay ikiz kız kardeş gibidir. "Bu şiir, toplumun her kesimine seslenen bir altkültür sanatı oluşmasını arzular." Tehditkâr, ürkütücü bir şiirdir. Ayrıntının kolajlandığı bu şiir; tiksindirir, bunaltır, şaşırtır, iğrendirir. Ayrıntının muzip çirkinliği gerçeğe tutunarak aktarılır. Bu şiirler birbirlerini tanımazlar, farklı enstrümanlardan çıkan ezgileri oluşturan notalardır. Salvotikler, ayrı noktaları işgal eder, ayrı noktaları çökertir. Deneyler yapar, önceki şiiri laboratuvar olarak kullanırlar. Sentezlere ulaşıp sonuç olarak fark elde ederler; sonuç önemsemedir. Bu şiirler asi, serseri, korkusuz ve bazen de sapkındır. Nedeni, normal şeklinde adlandırılanla düşülen polemiktir. Salvotikler; aile, eğitim, din kurumlarıyla boğuşur. Bu kurumların gelişmeye ket vurduğunu düşünerek taarruzu benimserler (2012, s.69-70).

\section{GÖSTERGE OLARAK “ÖPMEK” EYLEMI}

Marcel Danesi, Öpüşmenin Tarihi Popüler Kültürün Doğuşu adlı kitabında bir gösterge olarak "öpüşmek” eyleminin popüler kültürde ne anlama geldiğini ele almıştır. Kitapta filmlerden kurmaca ya da gerçek eserlere kadar "öpüşme" eyleminin çağrışımları ve bir sembol, mit, ritüel olarak toplumsal yaşamdaki gösterge değeri üzerinde durulmuştur. Göstergebilim disiplinini "İnsanların ürettikleri şeylerin anlamı nedir?" temel sorusu yönlendirir. "Varlıkbilimsel sorgulamanın genel çerçevesi olarak göstergebilim, öpüşmek gibi esrarengiz bir fiili anlamak için bunu bir sembol olarak ele almanın gerekliliğini vurgular. Estonyalı göstergebilimci Yuri Lotman, semiosphere (gösterge-küre) adını verdiği insan zihninin içine battı̆̆ semboller evreninde onu diğer anlam yapılarıyla birleştiren bir dizi anlamın temsilcisi gibi çalışmak gerektiğini öne sürer” (2013, s.39).

"Göstergebilim açısından ele alındığında öpme ve öpüşme sevgi, yakınlık, cinsellik gibi anlamların yanı sıra; değer verme, özlem, veda, minnet, kutsallık ve saygı ifadelerini de içerdiği görülmektedir." Öpme Giotto, Hayez, Rodin, Picasso, Klimt, Lautrec, Brancusi, Chagall, Magritte, Lichtenstein gibi sanatçıların eserlerinde; fotoğraf, sinema gibi diğer sanat alanlarında da önemli bir gösterge olarak ele alınabilir (Soylu, 2017, s.269).

Görsel sanat dallarından yazınsal sanat dallarına kadar "öpüşmek" eyleminin metaforik gücü, sanat eserinde bütünün bir parçası olarak yeniden kurgulanır. Sanatçı, yeniden ürettiği anlamda; "öpüşmek" eylemini ise toplumsal yaşamdaki algıları bazen bütünleyerek bazen reddederek bu eylemin sembolik değerini eserinde yadsımaz. Bu nedenle şiir, roman ya da farklı sanat dallarında "öpmek" eylemi cinsel çağrışımların çok daha ötesinde anlamlar içerir, sanatçı da bu eylemin çoğulladığı algıyı anlatmak istediği manayla birleştirir.

\section{“BIR NEDENI YOK YALNIZCA ÖPTÜM” ADLI Şİİİ OKUMA DENEMESİ}

küçük İskender'in Bir Nedeni Yok Yalnızca Öptüm adlı kitabı 2002 y1lında Om Yayınlarından çıkar. Daha sonra şair, Bir Nedeni Yok Yalnızca Öptüm, Kahramanlar Ölü Doğar ve Bahname adlı üç kitabını bir araya getirerek Karanlıkta Herkes Biraz Zencidir adıyla 2006'da yeniden yayımlar. Bir Nedeni Yok Yalnızca Öptüm adlı kitaba adını veren şiirin konu edildiği bu çalışmada anılan şiir, göstergebilim ve dilbilim alanlarından faydalanılarak incelenmiştir.

\section{a) Tekrar Ögesi}

Kitaba adını veren "bir nedeni yok yalnızca öptüm” adlı şiir, 13 bölümden oluşur. Şiir-metin demek daha yerinde olur, çünkü şiirde 13 bölüm blok birer paragraf hâlinde ve bir dize şeklinde kurgulanmıştır. 13 bölümün sonunda "Bir nedeni yok. Yalnızca öptüm." dizesi aynı cümle ve kelime düzeni, büyük-küçük harf yazımı korunarak tekrar edilir. Tekrar edilen dizede büyük-küçük harf düzeni korunurken kitapta, şiirin başlığındaki kelimelerin hepsi küçük harfle yazılmıştır. Şair, 13 bölüm için herhangi bir numaralandırma yapmamıştır. Numaralandırma, bu çalışmada yapılarak şiirin tahlili kolaylaştırmak istenmiştir. Yinelenen bu dize ile şiirin bölümleri birbirine bağlanır. Tekrar etmek şiirde hareketi, anlamın akışını sağlar.

küçük İskender, şiirde tekrar etmenin eylemi çoğalttığının, tekrar edilen kelimelerin yarattığı anlamın ve tekrarın ne işe yaradığının ise farkındadır: 
Şiirin bütününe yayılan 'kelime ya da kelime grubu tekrarları'! ${ }^{4}$ Bir tek biz değil, herkes yüzyıllardır "aynı şeyler"i söylerdi; bunun altını çizmek için denenmiş bir tekniktir o. Concept'i psikiyatri tescilli bir söylem. (...) Tekrar etmek, bireye insanî özellikler katar: Toprak kazmak, alkışlamak, nefes almak, 'seni seviyorum' demek ağlamak. Eylemi çoğullamak, şiir içinde de anlama yaşama coşkusu veriyor; en azından inatçı kişiliklerin şiire yansıması olarak da bakılabilir (2009b, s.72).

13 bölümde tekrar edilen dize, her bölümde bir bağlamla verilir. Tekrar edilen dize ile nedensiz, artniyetsiz bir öpmenin yaşandığı vurgulanır. İki kişi arasında yaşanan aşk, son bölümde ayrilıkla nihayetlenir. 13 sayısı dünya mitolojisinde ve semavi dinlerde farklı anlamları çağrıştırır. $\mathrm{Bu}$ şiirde ise yaşanan aşk 13.bölümde veda ile sonuçlanır.

Tablo 1. Şiirin bölümleri, bölümlerin odağındaki kelimeler ve tekrar ögesi

\begin{tabular}{|l|l|}
\hline $\begin{array}{l}\text { Şiirin Bölümleri, } \\
\text { İşlenen Konuyu Bütünleyen Sözcükler }\end{array}$ & $\begin{array}{l}\text { Şiirin Bölümlerinin } \\
\text { Sonlarında Tekrar Edilen Dize }\end{array}$ \\
\hline 1. öpme, sevişmek, ateş, yabancı. & "Bir nedeni yok. Yalnızca öptüm.” \\
\hline 2. uzay, yalnızlı, yıldızlar, tamamlanma. & "Bir nedeni yok. Yalnızca öptüm.” \\
\hline 3. çocukluk, çay, votka. & "Bir nedeni yok. Yalnızca öptüm.” \\
\hline 4. fedakârlık, sevmek, endişe, artniyetsizlik. & "Bir nedeni yok. Yalnızca öptüm.” \\
\hline 5. soruyu soru hâlinde bırakma, melankoli. & "Bir nedeni yok. Yalnızca öptüm.” \\
\hline 6. inanmak, hata yapmak, terk etmek, gece. & "Bir nedeni yok. Yalnızca öptüm.” \\
\hline 7. aşk, hakikat, beden, idealler, kalp. & "Bir nedeni yok. Yalnızca öptüm.” \\
\hline 8. huzur, günah, tanrı, kaybetmek, sevmek. & "Bir nedeni yok. Yalnızca öptüm.” \\
\hline 9. romantizm, uzaklaşmak, kaybediş. & "Bir nedeni yok. Yalnızca öptüm.” \\
\hline 10. bedel, kefalet, eksen kayması. & "Bir nedeni yok. Yalnızca öptüm.” \\
\hline 11. zayıflık, kifayetsizlik, aşk, endişe, telaş. & "Bir nedeni yok. Yalnızca öptüm.” \\
\hline 12. sevda siyaseti, yalnızlık, unutmak. & "Bir nedeni yok. Yalnızca öptüm.” \\
\hline 13. cüce çocuk, sevmek, veda. & "Bir nedeni yok. Yalnızca öptüm.” \\
\hline
\end{tabular}

“Bir nedeni yok. Yalnızca öptüm.” dizesi ile bitirilen her bölümde bir konu ele alınır. Birinci bölümde öpmek, sevişmek, aşk, ateş kavramları etrafında öpme eylemi konu edinilir. İki kişi arasında geçen aşk, öpme eylemiyle yansıtılır. Öpme eyleminin anlatıcısı aynı zamanda eylemi gerçekleştiren kişidir. Birinci bölümde kişi kendini "fuzuli bir beden" diye tanımlar (2010, s.57). Aşk seven kişinin tamamlanma duygusunu harekete geçirir. İkinci bölümde anlatıcı "Benimle tamamlanacak bir şeye benziyorsun çünkü” (2010, s.58) diye seslenir. Üçüncü bölümde aşk; insanı çocukluğa, saflığa götürür. Âşık, sevdiğine çocukluğunu anlatmak, onunla konuşmak ister. Dördüncü bölümde artniyetsiz, masallar ve efsanelerle sevdiğine geldiğini dile getirir. Beşinci bölümde "soruyu soru hâlinde bırakıp" gitmek ve "ortak bir açı" (2010, s.61) yakalayamamak söz konusu olur. Altıncı bölümde insanın hata yapabileceği, hata yapabilmenin doğal bir eylem oluşu belirtilir. Yedinci bölümde, aşkın akıl kadar beden gücü de

\footnotetext{
${ }^{4}$ Noktalama konusunda şairin imla tercihine sadık kalınmıştır.
} 
gerektirdiği, aşkın bağlanmakla ilgili sahiplenmekten öte bir tarafı anlatılır. Sekizinci bölümde ise ayrılık üzerinden doğanın işleyişi konu edilir. İki insanın birbirini hiç anlamadığı açığa çıkar. Dokuzuncu bölümde ise romantizm bitmiştir, özveri yok olmuştur. Yaşanan ayrılık onuncu bölümde eksen kaymas1 ile ifade edilir. On birinci bölümde yaşananlar "kelimelerin kifayetsiz olma" $\mathrm{s}^{5}$ ile bağdaştırılır. On ikinci bölümde sevilenin yokluğu, ayrılığın sonucunda yaşanan bunaltı yansitılır. Son bölüm olan on üçüncü bölüm ise ayrılığın gerçekleşmesi ve artık sevilene dokunamama hâliyle anlatılır, veda sözcüğü ile bitirilir.

\section{b) Alışılmamış Bağdaştırmalar (Sapmalar)}

Doğan Aksan, Şiir Dili ve Türk Şiir Dili adlı kitabında şiir dilindeki "sapma” kavramını, İngilizce "deviation” kelimesinin karşılığı olarak verir. Şiir dilinde sapmayı, ele alınan konu, sözcük seçimi, sözdiziminde bilinçli olarak değişikliğe gitmeyi, dilde olmayan yeni sözcük ve anlatım biçimlerini kullanma eğilimi olarak tanımlar. "Sanatçı bu eğilimle dile yeni bir güç kazandırmayı, göstergeleri ses ve anlam açısından daha etkili kılmayı, okuyanın/dinleyenin zihninde yeni değişik tasarımlar ve duygu değerleri oluşturmayı amaçlar” (1999, s.166). Berke Vardar'ın Açılamalı Dilbilim Terimleri Sözlüğünde, "sapma" terimi, bir dili konuşan kişilerin uydukları kuralların dışına çıkan her türlü kullanımı diye açıklanır (2002, s.164).

Ses (phonological), söz (lexical), yazımsal (graphological), anlamsal (semantic), sözdizimsel (syntactic), tarihsel (historical) (Çelik, 2015, s.76-91) olarak farklı dil sapmaları vardır. Ünsal Özünlü’nün Edebiyatta Dil Kullanımları kitabında anlamsal sapmalar, "alışılmamış söz dizimi ve alışılmamış sözcük seçimi (alışılmamış bağdaştırmalar)" olmak üzere iki başlık altında incelenir. Özünlü, Ece Ayhan ve Oktay Rifat'tan örnekler vererek söz dizimi ve sözcük seçiminin alışılmamış şekilde birlikte kullanılabileceğini de gösterir (2001, s.151).

küçük İskender'in şiirinde anlamsal sapmalar, dildeki salvolar olarak yorumlanabilir. küçük İskender'in şiirinde tekrar ögesi kadar belirleyici bir diğer öge ise alışılmamış bağdaştırmalardır. Öpme eyleminin aşktaki rolü; her bölümde ivmelenen duygunun ve durumun alışılmamış bağdaştırmalarla verilmesi şiirdeki lirizmi artırır. Alışılmamış bağdaştırmalar, dildeki sapmaların bir çeşididir. küçük İskender'in şiirinde, farklı dil sapmaları vardır. Alışılmamış bağdaştırma, farklı bağlamları olan iki kelimenin daha önce günlük dilde olmadığı şekilde edebî eserlerde bir arada kullanılması ile oluşturulur.

Ömer Lütfi İspirli hazırladığı "Almanca ve Türkçede Eğretileme Süreci” adlı doktora tezinde de küçük İskender'in şiirini alışılmamış bağdaştırmalar başlığı altında inceler. İspirli, küçük İskender'in şiirde soyutlama yeteneğinin altını çizer ve alışılmamış bağdaştırmanın farklı yapılarını küçük İskender'in nasıl kullandığına dair örnekler verir. Alışılmamış renk imgeleri, renk ikilemleri ve zıtlaşmalar, duygu ile kurulanlar, siyasi ve dinî düşüncelerle kurulanlar, doğa olgu ve nesneleri ile kurgulananlar, benzetme ve betimlemelerle yapılanlar, argo ile kurulanlar, tarihî gerçeklikle kurulanlar şeklinde farklı alışılmamış bağdaştırmalardan bahseder (2014, s.154-155).

"bir nedeni yok yalnızca öptüm"“6 adlı şiirde anlamsal alışılmamış bağdaştırmalar, şiirdeki ritmi belirler. Nedensiz bir öpme eylemi ile anlatılan aşk hâli her bölümde alışılmamış bağdaştırmalar ile ele alınır. Sözcük seçimi ve söz dizimi alışılmamış şekilde kurgulanır. Aşağılda verilen örneklerde anlamsal sapmaları bu açıdan değerlendirmek gerekir. Şiirdeki alışılmamış bağdaştırmalar şunlardır:

Tablo 2. Şiirdeki Anlamsal Sapmalara Örnekler

\begin{tabular}{|l|l|}
\hline Şiirden alıntı & Açıklaması \\
\hline “(...) korkunun biçim kazanıp ayağa kalktığı & $\begin{array}{l}\text { Korku, “ayağa kalkmak” eylemi ile somutlanır. } \\
\text { ve 'hey, bana bir şeyler söylemenin vakti } \\
\text { Ayağa kalkmak; gidişi sezdirirken, aynı cümlede } \\
\text { geldi’ dediği zamanlarda bekledim seni” } \\
\text { (s.57). }\end{array}$ \\
\hline
\end{tabular}

\footnotetext{
${ }^{5}$ Şair Orhan Veli'ye atıfta bulunur.

${ }^{6}$ Şiirin başlığı bu şekilde yazılmıştır, aynı adlı şiir kitabının adı büyük harflerle (BİR NEDENİ YOK YALNIZCA ÖPTÜM), şiirin bölümlerinde tekrar dizesi cümle düzeninde (Bir Nedeni Yok. Yalnızca öptüm.) yazılmıştır.
} 
"Bilmiyordum, kelimelerden arınmış bir cümle kurar gibi sevişmeyi. Sevişirken sözlük kullaniyordum hâlâ" (s.57).

“Fuzuli bir beden” (s.57). Romantizme uyum sağlamak için de değil" (s.58).

"Çaydanlığa su yerine votka koyarız sen dilersen” (s.59).

"Hacimler açarım sana içimde, dolman için, oraya akman için. Hacimler açarsın bana, çağlayarak gelirim" (s.59).

"Bedenlerin bedenlerden istedikleri, ruhların ruhlardan çıarttıkları, karşılıklı acıların birbirlerinin etkisini arttırdıkları vakitlerde düştün aklıma. Aklıma yayıldın" (s.61). yaşayabilmenin yalnızlı̆̆ıdı bu” (s.61).
"Yağmurlar başka galaksilerden gelip yağar.

Sevişmek eylemi ile cümle kurmak eylemi bir arada kullanılarak kelimeler standart dilin dișında bir kullanımla bir araya getirilmiştir.

Bedene olan inanç, boşluk ve hiçlik duygusu ile tanımlanır; insanın varoluşunu aşkla gerçekleştirebileceği anlamı yansıtılır.

Şair, romantik bir öge olan "yağmur"u bilinen bağlamından uzaklaştırır. "Galaksi" kelimesi ile seste de lirizmi yaratır.

Çaydanlık sözcüğü ile votka sözcüğü bir araya getirilir, su yerine votka konulmak istenir; böylelikle dizge parçalanır.

"Hacim” kelimesi aşkın bir parçası olarak cümlede alışılmamış bir şekilde kullanılır. Hacim, insanın bedende ve zihninde başka birine yer açması anlamını verir.

Beden kelimesi insanı anlatır, ancak insan yerine beden kelimesi kullanılarak alıșılmamış bir cümle düzeni kurulur. Ruh-beden ilişkisi ise acı duygusu ile verilir. Daha önceki bölümde geçen "hacim", algıs "aklıma yayıldın" olarak somutlanır. Aklına gelmek deyimi değiştirilir.

"Mal varlığı" ifadesi ile aşkta insanın hükmetme gücü sorgulanır. Bir insanın diğerinin "malı" belki de üstünde söz sahibi olduğu bir eşyaya dönüşmeden gerekirse yalnız yaşaması gerektiği sezdirilir.

"İnsan inandığ hatalar da yapabilir" (s.62).

"Demokrasi senin saçlarından güzel olamaz" (s.62).

"Dünyanın en uzun gecesi 21 Aralık değil, beni terk ettiğin gecedir" (s.62).

“İnsanlığa karışmaya hazır yapışık kalpler taşıyoruz aşkımızda. Bizim aşkımız, hakikaten beden gücü gerektiriyor akıl kadar" (s.63).

"Aynı otobandaydık ve birimiz birimizin yanından geçip gitti. Hafizasızlığ saymanın adil yanı!" (s.64)
"Hata" ve "muhteșem" sözcükleri bir arada kullanılarak bilinen sözcük düzeni ve sıralaması değiştirilir.

"Demokrasi" ile "saç" sözcükleri alışılmamış bir bağlamda kullanılır.

Ayrılık acısı, bilinen bir coğrafi terimi reddedişle yansitilir.

Așkın sadece duygu ve akıl değil, beden gücü gerektirdiği vurgulanır. Aşkın sadece duygu ve akıl ile kurgulandığ ifadesi de katılarak anlam yeniden yaratılır.

"Otoban" kelimesi ile yalnızlık anlamı verilir. Unutmak ise "hafizasızlık"tır. Otoban, hız sınırının olmadığı yol anlamıyla; okura, sınırsızlık algisinı verir. 
"İnsan, özverinin çocuklara ad olarak verilebileceği bir dünyada tanımını kaybediyor, miladını kaybediyor, peygamberlerini kaybediyor. Bu kaybedişteki kaosun ritmiyle çekiliyorum sana. Sen bir mıknatıssın şeffaf ve ben, çekilirken sana içimdeki alelade metal parçalarıyla, kan şekerim düşüyor, tansiyonum düşüyor, ağrılarım düşüyor, ağzım düşüyor, ellerim... en çok da ellerim düşüyor!” (s.65)

"Bu da soysuzlaşmanın, aşkın getirdiği dalaveralarla kendine kilitlenmenin başka bir çeşidi! Peki, anahtar nerede sevgilim?! Peki anahtarın üzerindeki yivler kimin eseri?!" (s.67)

"Seni unutmama kaç yüzyıl kaldı ki.. Bir küsme, bir burulma biçimiyle gidișinin ardından şehrin gri cephelerine fevkalade ağır bir el bombası gibi düşen bunaltının bıraktığ korkunç acının unutulmasına kaç yüzyıl kaldı ki.. (...) Ölü de var dudaklarımda. Çı̆̆rından çıkmış bir ayaklanma gibi ağlamakta yalnızlığım. (..) Ama yokluğunu doldurmuyor sevda siyasetinin hançerleri" (s.68).

"Ben bir cüce çocuk sevdim sende sıska. (...) $\mathrm{O}$ rutubet kokan loş yüzündeki kanalizasyonları, az kelimeyle kurduğun cümlelerindeki gizli soru işaretlerini, barlardan çatlak bir bardak gibi atılmayı beklemeni, serserice patlamalarını, yuttuğun toplu iğneleri ve bir film hissi uyandıran utangaç hasret poyrazlarını sevdim" (s.69).
Toplumsal yaşamı düzenleyen zaman ögesi "milad”, din ögesi "peygamber" sözcükleri; farklı bir bağlamda kullanılmıștır. Özverinin, fedakârlığın yok oluşu; anlam yitimiyle verilir. Tıbbi terimler ile duygular aktarılmıştır: kan şekeri düşmek, tansiyonu düşmek. $\mathrm{Bu}$ terimler ağrı kelimesiyle bağlanarak ağız ve el kelimeleriyle düşmek eylemi kullanılarak alışılmamış birleşik eylem yapılmıştır. Ac1 çekmek duygusu pekiştirilmiştir. Kaybetmek sadece aşktaki bir duygu olarak değil, dünyadaki kaybedişle ve kaosla harmanlanmıştır.

Anahtar; iki insanın ilișkisini tanımlayan bir araç olarak ele alınır, ilișkiyi somutlayan bir kelimedir. Anahtarın üzerindeki yivler, aşkta insanın diğer kişide açtığı yaralar, oyuklar, çıkıntılar olarak sezdirilir.

"Cephe, el bombası" farklı bir bağlamda kurgulanır. Savaşa dair unsurlar, yaşanan aşktaki acıyı tarif etmek için kullanılır. Unutmak eylemi, yüzyıl sözcüğü ile bir araya getirilerek anlam abartılır. "yalnızlığın ayaklanması", "sevda siyasetinin hançerleri”" alıșılmamış bağdaştırmalardır.

Savruk, tutarsız gibi sıralanan olumsuz kelimeler sıralanarak şiirde bombardıman etkisi yaratılmak istenir. Şair, okuru sözcüklerle topa tutar; âdeta yaylım ateşi açar. Bütün bu saldırı ise "sevmek" eylemi ile sonlandırılır. Sevgi, sevilenden bağımsızdır.

\section{c) Gönderen ve Alıcı İlişkisi Bağlamında “Öpmek” Eylemi}

Fatma Erkman, öpme eylemini toplumsal ilişki dizgesi olarak inceler ve öpme eylemini iki nedene bağlar. Birincisi cinsel düzlemde birbirine karşı ilgi duyan kişiler arasındaki öpme edimi, ikincisi ise toplumsal düzlemde (aile, resmî bir kurum gibi) kişiler arasında gerçekleşen geleneksel öpme edimi (1987, s.107). Umberto Eco'nun gösterge ve dizge yaklaşımını benimseyen Erkman, geleneksel öpme edimini inceler ve öpmenin somut bir edim olduğunu belirterek bir bildirişim şeması çizer:

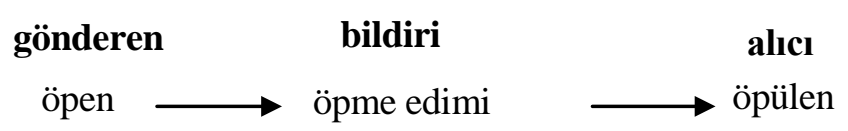


Fatma Erkman, bu şemayı toplumsal yaşamdaki öpme edimi bağlamında yorumlar, ancak bu şemayı cinsel düzlemde birbirine karşı ilgi duyan kişiler arasında gerçekleşen öpme edimini yorumlamak için de kullanabiliriz. Öpüşmek, "metaforik bir düğümdür, dudaklar arac1lığıyla iki bedeni ve iki ruhu birleştirir" (Danesi, 2015, s.45). "Öpüşmek âşıkları, yaşamda ve ölümde kalıcı bir şekilde birbirlerine bağlayan güçtür” (s.113). Öpüşmek, cinsel düzlemde karşılıksız kalır paylaşılmazsa, iki ruh birleşemez. Öpüşmenin paylaşılması ise aşkın yaratılmasını ve ortaya çıkmasını sağlar.

küçük İskender'in şiirinde bu şemayı oluşturduğumuzda; "sevilen”, “seven”in öpücüğünü paylaşmaz. Öpme ediminin, dudaktan gerçekleştiği şiirin başında söylenir: "dudaklarım gerisin geriye çekildi; ağdalı bir sıvının ağır ağır örttüğü (...)"(küçük İskender, 2010, s.57). "Alıcı", yani "sevilen” bu öpücüğü paylaşmamıştır. küçük İskender, güncesinde "dudaklardır bir vücudun başkenti" (2012, s.74) derken de dudakların bedendeki önemine dikkat çeker.

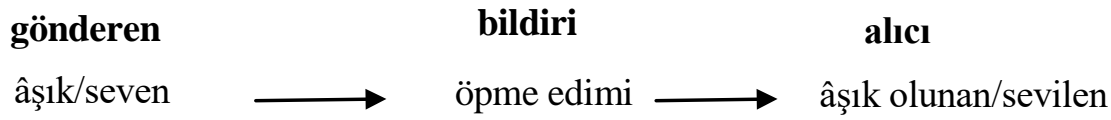

“Gönderen” ve "alıcı" arasındaki öpme edimi paylaşılmamıştır, şiirin devamında da birinci tekil anlatım kullanılarak seven kişinin duyguları yansıtıılır. Şair, ayrılık acısını, el bombasına benzetir (2010, s.68);

"Dünyanın en uzun gecesi 21 Aralık değil, beni terk ettiğin gecedir" (2010, s.62) der. İnsanın kendisi dışında bir kişiye hayranlık duymasının, kişiyi sevmesinin ise kabahat olmadığını vurgular. Şiir saf, kaba, ilkel bir cinsellik üzerine kurulmamıştır; şiirdeki öpme edimi bir aşkı başlatmayan, boşlukta kaybolan, paylaşılmayan bir aşkı somutlaştırmak için bir gösterge olarak kullanılmıştır. Sözcük seçimi, dizge dışı kullanımları ile şair, dilin sistematiğini parçalar. Bunu yaparken tekrarlardan, alışılmamış bağdaştırmalardan yararlanır.

\section{SONUÇ}

Türk dilinin olanaklarını ve sınırlarını keşfederek şiirini kurgulayan küçük İskender, karşı1ıksız sevgiyi öpme eylemi ile somutlaştırır. Şiirde somut bir öpme eylemine odaklanarak karşılıksız sevgiyi, etkili bir atmosferle yansıtır. "bir nedeni yok yalnızca öptüm" adlı şiirde, karşılıksız sevmenin somut göstergesi olarak "öpmek" ediminden yararlanılmıştır. Gönderen (seven) ve alıcı (sevilen) arasındaki öpme edimi paylaşılmamıştır. Gönderen-alıcı arasındaki iletişimsizlik, alışılmamış bağdaştırmalar ve tekrarlarla dile yansıtılmıştır. Normatif yaşama karşı pencereden bakan küçük İskender, şiirlerinde ve eserlerinde toplumsal yaşamın dayatmalarına ilişkin eleştirel tutumunu her zaman korumuştur. 1980'lerden 2000’lere uzanan şiir serüveniyle modern Türk şiirine yeni bir soluk getirmiştir. Ortadoğu, eşcinsellik, queer, kentli faşizm, Beyoğlu, cinsiyet algısı, şairlik, çocukluk, Beat yazarları, rakı, beden algısı, müzik, sinema gibi farklı konularda yazmıştır. Onun dili kullanma şeklini dildeki salvolar olarak yorumlamak mümkündür. Gücünü savunmadan değil taarruzdan alan şiirinin merkezinde; parçalanma, bölünme ve yalnızlık vardır. Kelimeleri kullanırken, cümleleri düzenlerken standart dildeki bağlamlarından koparır. Dil dizgesini bozar, alışılmamış bağdaştırmalarla kelimelerin yeni anlamlar oluşturmasını sağlar. Onun şiirleri, okur üzerinde bombardıman etkisi yaratır. Argo, küfür, kaba sözler kullanmaktan çekinmeyen şair, argonun yaratıcılık gerektirdiğini dile getirir. küçük İskender'in şiiri, samimiyet, gerçekçilik ve dikbaşlı bir söylemden vazgeçmemesi ile karakter kazanır. Yaşamını şiirle ve edebiyatla şekillendiren şair üzerine bütünlüklü bir çalışma henüz yapılmamıştır. Şiirleri ve yazıları yeni okumaları hak eden küçük İskender, Türk şiirinde modernleşmenin önemli bir temsilcisidir.

\section{Bilgilendirme / Acknowledgement:}

Yazar aşağıdaki billgillendlirmeleri yapmaktadır:

1- Makalemizde doküman incelemesi yapıldığından etik kurulu izni ve/veya yasal/özel izin alınmasını gerektiren bir durum yoktur.

2- Bu makalede araştırma ve yayın etiğine uyulmuştur. 


\section{KAYNAKÇA}

Aksan, D. (1999). Şiir dili ve Türk şiir dili. Ankara: Engin Yayınevi.

Celâl, M. (1993). küçük İskender 'Türkçe yazsam da Türk şiirinin dışındayım' (küçük İskender'le söyleşi). Sombahar, 17, 59-64.

Çelik, A. (2015). Nilgün Marmara'nın şiirlerinde dil sapmaları. Uluslararası Türk Dünyası Kültür Araştırmaları Dergisi, 1, 7-99.

Danesi, M. (2015). Öpüşmenin tarihi popüler kültürün doğuşu. (Çeviren: Özlem Karadağ). İstanbul: Doğan Kitap.

Erkman, F. (1987). Toplumsal ilişki dizgesi olarak 'öpme’. Göstergebilime giriş içinde. 107-118. İstanbul: Alan Yayıncilik,

İspirli, Ö. L. (2014). Almanca ve Türkçede eğretileme süreci. Ankara Üniversitesi Sosyal Bilimler Enstitüsü, Yayımlanmamış doktora tezi, Ankara.

küçük İskender, (2009a). Underground otopark. İstanbul: Sel Yayıncılık.

küçük İskender, (2009b). Rimbaud'ya akıl notları. İstanbul: Sel Yayıncılık.

küçük İskender, (2010). Karanlıkta herkes biraz zencidir. İstanbul: Sel Yayınc1lı.

küçük İskender, (2012). Cangüncem. İstanbul: Sel Yayıncılık.

küçük İskender, (2013). Eflatun sufleler. İstanbul: Sel Yayıncılık.

küçük İskender, (2018). İkinci waliz. İstanbul: Can Yayınları.

Özkarc1, A. Ö. (2014). küçük İskender: 'yaşasın kötülük!', underground ve bizim looser’lar. Cetvelle çizilmiş dă̆ınıklık içinde. 87-115. İstanbul: 160. Kilometre.

Özünlü, Ü. (2001). Edebiyatta dil kullanımları. İstanbul: Multilingual.

Soylu, R. (2017). Sanatta ve kültürde öpme ritüelinin göstergebilim açısından incelenmesi. Elektronik Sosyal Bilimler Dergisi, 16(60), 269-287.

Vardar, B. (2002). Açıklamalı dilbilim terimleri sözlüğü. İstanbul: Multilingual. 